\title{
Comparison of Employment Generation in Organized and Unorganized Markets of Kolkata City
}

\author{
S. Sinha" and Md. H. Ali
}

Department of Agricultural Economics, Bidhan Chandra Krishi Viswavidyalaya, Mohanpur, Distt. Nadia, West Bengal, India

*Corresponding author: shalini5621@gmail.com (ORCID ID: 0000-0003-3856-7398)

Received: $28-11-2020$

Revised: $12-03-2021$

Accepted: 06-03-2021

\begin{abstract}
Retailing is defined as a set of activities involved in the selling of a product or service to definite customers ranging from vehicles to clothing to feast at restaurants to film tickets. Somayajulu et al. (2002) found several hurdles hampering the growth of organized retail in India. These hurdles included high intermediation, high supply chain costs, insufficient supply chain infrastructure, inflexible labor laws, multiple licensing requirements, etc. Retailers along these lines attempt different business exercises and perform capacities, for example, arranging, holding stock, and so on, that increase the value of the contributions they make to the objective sections. The retail industry is divided into two parts- Organized Retail Sector and Unorganized Sector. The research study intends to analyze the volume and nature of employment generated between organized and unorganized sectors of Kolkata. The study reveals that unorganized sector retailers did experience a slight decline in their volume of business and profit in the initial years after the entry of large organized retailers, but there was no evidence of a decline in overall employment in the unorganized sector as a result of the entry of organized retailers and hence none of the retailers would like to change their existing business in spite of having sufficient resources for changing business because all of them do not find any reason to change business.

\section{Highlights}

0 The unorganized sector retailers did experience a slight decline in their volume of business and profit in the initial years after the entry of large organized retailers, but none of the retailers would like to change their existing business in spite of having sufficient resources for changing business, because all of them do not find any reason to change business.
\end{abstract}

Keywords: Retailing, traders, unorganized market, organized market

Retailing encompasses of a set of activities involved in the selling of a product or service to definite customers ranging from vehicles to clothing to feast at restaurants to film tickets. The word 'retail' comes from the French word 'retailer', which signifies 'to cut a piece off or 'to break mass'. A retailer is a person, agent, agency, company, or organization which is instrumental in reaching the goods, merchandise, or services to the ultimate consumer. The retail industry is divided into two partsOrganized Retail Sector and Unorganized Sector. Unorganized retailing indicates the traditional formats of low-cost retailing, such as local Kirana shops, owner-manned general stores, chemists, footwear shops, apparel shops, hand-cart hawkers, pavement vendors, etc., whereas, Organized retailing refers to trading activities undertaken by licensed retailers, includes the corporate-backed hypermarkets.

The Indian retail sector is highly segregated, consisting predominantly of small, independent,

How to cite this article: Sinha, S. and Ali, Md. H. (2021). Comparison of Employment Generation in Organized and Unorganized Markets of Kolkata City. Economic Affairs, 66(1): 157-167.

Source of Support: None; Conflict of Interest: None

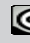


owner-managed shops. The domestic organized retail industry is at a developing stage. At the macro-level, factors such as rising disposable income, the dominance of the younger population in spending, urbanization, a shift of the traditional family structure towards the nuclear family are supporting the growth of organized retail growth in India. On the one hand, the advancement of information technology is improving end-to-end business processing by integrating the entire value chain, backward and forward, for operational efficiencies. On the other hand, rising real estate prices, infrastructure constraints, and expensive technology are making the retail industry capital intensive.

Nonetheless, with the help of the macroeconomic landscape, the domestic retail industry has immense scope for modern as well as traditional retailers to co-exist. Through a balanced regulatory framework and competition policy, both the traditional format and the modern format can continue to grow, eventually closing the gap between the organized and unorganized sectors. Organized retailing will: (i) promote quality employment; (ii) improve business process practices; (iii) encourage investments in support industries; and (iv) enables the modernization of the fragmented traditional retail industry.

The modern retail business gives importance to maximizing customer footfalls and capturing rising volume and share of the customer wallet. While the competition strategy is largely pricefocused, the model works by (i) improving sourcing efficiencies; (ii) expanding product assortment; (iii) differentiating service and (iv) improve the store ambiance. Thus, there are four drivers of modern retail's "one-stop shopping model": price, product, service, and ambiance.

\section{Indian Retail Scenario}

Indian retail is one of the quickest developing organizations on the planet market because of monetary development. The Indian retail industry is currently ranked 4th in the world and contributed 10 percent to India's GDP and 8 percent to the overall employment generation in the country. The market size was USD 0.79 trillion in 2019 and is estimated to reach USD 1.75 trillion by 2026, with a CAGR of 9 per cent-11 percent. However, approximately 88 percent of the market is in the unorganized segment, while organized and e-commerce accounts for the remaining share. India ranked 63 in the World Bank's Doing Business 2020 publication. India ranked 73 in the United Nations Conference on Trade and Development's Business-to-Consumer (B2C) E-commerce Index 2019.

(Source: According to a report by ANAROCK and Retailers Association of India (RAI), 2020.

\section{Objective and Methodology}

The objective of the study is to compare the volume and nature of employment generated between organized and unorganized sectors. The study is strictly based on primary information collected through canvassing a pre-ordained questionnaire among the selected traditional retailers as well as organized retailers to fulfill the objectives set out. Relevant data are collected from primary sources. The survey operation was carried out within 30-kilometer radii from central Kolkata. The study area is divided into 5 parts (Clusters):

1. Sealdah

2. Gariahat

3. South Dumdum

4. Gopalpur

5. Newtown

\section{Selection of study area}

Within each of the 5 different parts of the study area, 5 organized malls have been purposively selected firstly because in all the selected clusters both organized and traditional retail outlets are coexisting side by side and secondly, all the selected, organized outlets are dealing in both agricultural and non-agricultural commodities.

1. Sealdah- Big Bazaar

2. Gariahat-Spencer's

3. South Dumdum- Reliance Fresh

4. Gopalpur- Vishal Mart

5. Newtown- More

The information about the number of traditional markets situated around a $5 \mathrm{kms}$ radius of each of the selected, organized malls is collected. There are altogether 47 traditional markets distributed over the 5 selected, organized malls. Out of 47 traditional 
markets, we have selected proportionately 12 markets ( $25 \%$ of the number of traditional markets) for the collection of information. Thus the selected traditional markets are as follows:

1. Sealdah - Entally market, Baithakhana market, Jhanbajar market

2. Gariahat -Gariahat market, Panditya market

3. South Dumdum- Nagerbajar Market, Subhashnagar Market,Kalindi Market

4. Gopalpur- Teghoria Market, Baguihati Market

5. Newtown- Pakpole Market, Newtown Market

\section{Selection of sample}

The unit of observation is retailers and customers. The list of retailers is collected in each market and classified dry agricultural retailers into 2 categories i.e., big retailers (more than 50 sq meter ) and small retailers (less than $50 \mathrm{sq}$ meters) based on the area of the establishment. Similarly, in the case of wet agricultural retailers, the traders are classified into 2 categories i.e, big retailers (selling more than 5 commodities) and small retailers (selling less than 5 commodities) according to their number of wet (vegetables/fruits) retailing commodity.

From the list of dry-big categories and small-dry category of traders, we have selected 5 traders each by the method of random sampling. Therefore there are 10 dry categories of traders. Similarly, following the same procedure from the list of big-wet and small-wet category of traders, we have selected 5 traders each in the case of vegetable traders and fruits traders respectively by the method of random sampling. Therefore there are 20 wet categories of traders. Thus, we have selected 30 trading units from each of our selected traditional markets distributed over 5 zones.

\section{Collection of data}

Collection of data was made by visiting and interrogating each and every sample respondent with the help of a set of pre-tested survey schedules. Both tabular and statistical analyses have been made to analyze and interpret the data in order to get desirable results from the study. The compound annual growth rates (CAGR) of average monthly salaries of laborers in the 5 different zones of Kolkata over the time period before the establishment of organized retail outlet and after the establishment of organized retail outlet in each of the selected area have been calculated and are presented in tabular form which showed a positive-sum game in which both unorganized and organized retail can not only coexist but also grow substantially in size.

CAGR was worked out by:

CAGR $=(\text { Final year value } / \text { Initial year value })^{1 / t}-1$

Where, CAGR= Compound Annual Growth Rate; $t=$ time in years

\section{RESULTS AND DISCUSSION}

Results of the research study are presented in the form of tabular analysis, which is as follows:

Table 1 shows the other important features of the outlets in the traditional markets adjacent to the organized retail outlets when all the clusters are considered as a whole. It is understood from the table that the maximum number of the outlets are self-started outlets as compared to some grocery outlets that have been inherited from their respective fathers.

Table 1: Frequency Distribution on the basis of Age of the Traditional outlets in the Traditional Markets (Cluster-Pooled) (2016-17)

\begin{tabular}{lllll}
\hline \multirow{2}{*}{ Type of Traders } & \multicolumn{4}{c}{ Outlet Started by } \\
\cline { 2 - 5 } & Self & Father & Partner & Total \\
\hline Cluster-Sealdah & $82(91.11)$ & $8(8.88)$ & $0(0.00)$ & $90(100)$ \\
Cluster-Gariahat & $59(98.33)$ & $1(1.66)$ & $0(0.00)$ & $60(100)$ \\
Cluster-South & $86(95.55)$ & $4(4.44)$ & $0(0.00)$ & $90(100)$ \\
Dumdum & & $1(1.66)$ & $0(0.00)$ & $60(100)$ \\
Cluster-Gopalpur & $59(98.33)$ & 100 & $60(100)$ \\
Cluster-Newtown & $58(96.66)$ & $2(3.33)$ & $0(0.00)$ & 60 \\
\hline Grand Total & $344(95.55)$ & $16(4.44)$ & $0(0.00)$ & $360(100)$ \\
\hline
\end{tabular}

Figures in the parentheses indicate the percentages to the total (row-wise), $n=$ Sub sample.

Table 2 demonstrates important features of the outlets in the traditional markets adjacent to the organized retail outlets in all the clusters. The table shows that in all the clusters, the maximum age of the outlets varies from 21 to 30 years and the working experience age or period of the retailers varies 20 to 30 years in all of the selected traditional markets. 
$\underset{\text { AESSRA }}{\sqrt{U}}$ Sinha and Ali

Table 2: Frequency Distribution on the basis of Age of the Traditional outlets in the Traditional Markets (ClusterPooled) (2016-17)

\begin{tabular}{|c|c|c|c|c|c|c|c|c|c|c|}
\hline \multirow{2}{*}{ Type of Traders } & \multicolumn{5}{|c|}{ Age of the Outlet } & \multicolumn{5}{|c|}{ Working Experience period of the Retailer } \\
\hline & $<10 \mathrm{yrs}$ & $10-20 \mathrm{yrs}$ & $21-30$ yrs & $<30$ yrs & Total & $<10$ yrs & $10-20 \mathrm{yrs}$ & $20-30 \mathrm{yrs}$ & $<30 \mathrm{yrs}$ & Total \\
\hline Cluster - Sealdah & $0(0.00)$ & $28(31.11)$ & $53(58.88)$ & $9(10)$ & $90(100)$ & $0(0.00)$ & $\begin{array}{l}33 \\
(36.66)\end{array}$ & $56(62.22)$ & $2(2.22)$ & $90(100)$ \\
\hline Cluster-Gariahat & $1(1.66)$ & $24(40)$ & $31(51.66)$ & $4(6.66)$ & $60(100)$ & $0(0.00)$ & $24(40)$ & $26(43.33)$ & $\begin{array}{l}10 \\
(16.66)\end{array}$ & $60(100)$ \\
\hline $\begin{array}{l}\text { Cluster-South } \\
\text { Dumdum }\end{array}$ & $0(0.00)$ & $35(38.88)$ & $51(56.66)$ & $4(4.44)$ & $90(100)$ & $0(0.00)$ & $\begin{array}{l}33 \\
(36.66)\end{array}$ & $56(62.22)$ & $1(1.11)$ & $90(100)$ \\
\hline Cluster-Gopalpur & $0(0.00)$ & $26(43.33)$ & $31(51.66)$ & $3(5)$ & $60(100)$ & $0(0.00)$ & $\begin{array}{l}26 \\
(43.33)\end{array}$ & $31(51.66)$ & $3(5)$ & $60(100)$ \\
\hline Cluster-Newtown & $1(1.66)$ & $24(40)$ & $32(53.33)$ & $3(5)$ & $60(100)$ & $0(0.00)$ & $\begin{array}{l}25 \\
(41.66)\end{array}$ & $26(43.33)$ & $9(15)$ & $60(100)$ \\
\hline Grand Total & $2(0.55)$ & $\begin{array}{l}137 \\
(38.05)\end{array}$ & $198(55)$ & $23(6.38)$ & $360(100)$ & $0(0.00)$ & $\begin{array}{l}141 \\
(39.16)\end{array}$ & $\begin{array}{l}194 \\
(53.88)\end{array}$ & $25(6.94)$ & $360(100)$ \\
\hline
\end{tabular}

Parenthesis indicate the percentages in the total (row-wise), $n=$ sub sample size.

Table 3: Frequency Distribution on the basis of working hours of the Traditional outlets in the Traditional Markets (Cluster-Pooled) (2016-17)

\begin{tabular}{llllllll}
\hline \multirow{2}{*}{ Type of Traders } & \multicolumn{3}{c}{ Working hours } & \multicolumn{3}{c}{ Number of closing day } \\
\cline { 2 - 7 } & $<8$ hrs & $\mathbf{8 - 1 0 h r s}$ & $\mathbf{1 0 h}$ & Total & NIL & 1 Day & Total \\
\hline Cluster-Sealdah & $8(8.88)$ & $60(66.66)$ & $22(24.22)$ & $90(100)$ & $60(66.66)$ & $30(33.33)$ & $90(100)$ \\
Cluster-Gariahat & $6(10)$ & $34(56.66)$ & $20(33.33)$ & $60(100)$ & $40(66.66)$ & $20(33.33)$ & $60(100)$ \\
Cluster-South Dumdum & $7(7.77)$ & $58(64.44)$ & $25(27.77)$ & $90(100)$ & $60(66.66)$ & $30(33.33)$ & $90(100)$ \\
Cluster-Gopalpur & $5(8.33)$ & $36(60)$ & $19(31.66)$ & $60(100)$ & $40(66.66)$ & $20(33.33)$ & $60(100)$ \\
Cluster-Newtown & $9(15)$ & $35(58.33)$ & $16(26.66)$ & $60(100)$ & $60(100)$ & $0(0.00)$ & $60(100)$ \\
\hline Grand Total & $35(9.71)$ & $223(61.94)$ & $102(28.33)$ & $360(100)$ & $260(72.22)$ & $100(27.77)$ & $360(100)$ \\
\hline
\end{tabular}

Parenthesis indicate the percentages in the total (row-wise), $n=$ Sub sample size.

Table 3 shows the frequency distribution of the traditional outlets on the basis of working time in the traditional markets when all the clusters are considered as a whole (2016-17). From the table, it is noticed that most of the outlets remain open for 8 to 10 hours per day and the corresponding minimum figure is seen in case of working hours less than 10 . It is also observed from the table that all the grocery outlets (which accounts for 33.33 percent in all the cases) of the selected traditional outlets remains closed once a week whereas, the fruits and vegetable markets (which accounts for 66.66 percent) remains open every day in all the clusters.

Table 4 depicts the frequency distribution of the family members of the hired labor of the selected traditional traders when all the clusters are considered as a whole (2016-17) on the basis of educational qualification. It is clear from the table that most of the hired labor in the grocery, vegetables, and fruits market is illiterately, followed by literates and primary level of educational qualification.

Table 5 Presents the change in average labor (number of laborers utilized per traditional retail outlet 2010-11 to 2016-17) in cluster Sealdah. From the table, it is noted that the number of average hired labor has increased in all cases, but the number of family laborers has either decreased or remained the same in almost all the cases. It is seen that an average number of laborers per traditional outlet is increased if family and hired laborers are considered as a whole. It is further noted that the compound annual growth rates (CAGR) of average per month salary of laborers have increased in all traditional markets in the cluster Sealdah from 201011 to 2016-17 (i.e., before and after the establishment of the organized outlet in the area) which shows a positive change and hence there is no evidence of a decline in overall employment in the unorganized sector as a result of the entry of organized retailers. 
Table 4: Classification on the basis of Education Qualification of Hired Labours (Cluster-Pooled)

\begin{tabular}{lllllll}
\hline \multirow{2}{*}{ Type of Traders } & \multicolumn{5}{c}{ Education Qualification of Labours } \\
\cline { 2 - 6 } & Illiterate & Literate & Primary & Secondary & Higher secondary & Total \\
\hline Cluster-Sealdah & $55(59.78)$ & $29(31.52)$ & $8(8.69)$ & $0(0.00)$ & $0(0.00)$ & $92(100)$ \\
Cluster-Gariahat & $33(47.14)$ & $29(41.42)$ & $8(11.42)$ & $0(0.00)$ & $0(0.00)$ & $70(100)$ \\
Cluster-South Dumdum & $43(51.19)$ & $34(40.47)$ & $7(8.33)$ & $0(0.00)$ & $0(0.00)$ & $84(100)$ \\
Cluster-Gopalpur & $28(45.90)$ & $29(47.54)$ & $4(6.55)$ & $0(0.00)$ & $0(0.00)$ & $61(100)$ \\
Cluster-Newtown & $43(61.42)$ & $21(30)$ & $6(8.57)$ & $0(0.00)$ & $0(0.00)$ & $70(100)$ \\
\hline Grand Total & $202(53.58)$ & $142(37.66)$ & $33(8.75)$ & $0(0.00)$ & $0(0.00)$ & $377(100)$ \\
\hline
\end{tabular}

Figures in the parentheses indicate the percentages to the total (row wise), $n=$ Sub sample size.

Table 5: Change in Average Labour Utilized Per Traditional Retail Outlet from 2010-11 to 2016-17 (ClusterSealdah) (No of Employees per Outlet)

\begin{tabular}{|c|c|c|c|c|c|c|c|c|c|c|c|c|}
\hline \multirow[b]{2}{*}{ Type of Traders } & \multicolumn{4}{|c|}{ 2016-17 } & \multicolumn{4}{|c|}{ 2010-11 } & \multicolumn{4}{|c|}{ Change from 2010-11 to 2016-17 } \\
\hline & $\begin{array}{l}\text { Hired } \\
\text { Labour }\end{array}$ & $\begin{array}{l}\text { Family } \\
\text { Labour }\end{array}$ & Total & $\begin{array}{l}\text { Average } \\
\text { per } \\
\text { month } \\
\text { salary }\end{array}$ & $\begin{array}{l}\text { Hired } \\
\text { Labour }\end{array}$ & $\begin{array}{l}\text { Family } \\
\text { Labour }\end{array}$ & Total & $\begin{array}{l}\text { Average } \\
\text { per } \\
\text { month } \\
\text { salary }\end{array}$ & $\begin{array}{l}\text { Hired } \\
\text { Labour }\end{array}$ & $\begin{array}{l}\text { Family } \\
\text { Labour }\end{array}$ & Total & $\begin{array}{l}\text { CAGR of } \\
\text { Average } \\
\text { per } \\
\text { month } \\
\text { salary }\end{array}$ \\
\hline Traditional & & & & & & & & & & & & \\
\hline $\begin{array}{l}\text { Grocery Entally } \\
(\mathrm{n}=10)\end{array}$ & 1.7 & 0.7 & 2.9 & 7513.00 & 0.6 & 1.2 & 2.0 & 5459.00 & 1.1 & $-(0.5)$ & $0.6(-30)$ & 1.97 \\
\hline $\begin{array}{l}\text { Traditional Grocery } \\
\text { Baithakhana }(n=10)\end{array}$ & 1.9 & 1.1 & 3.4 & 7267.00 & 0.8 & 1.5 & 2.0 & 5350.00 & 1.1 & $-(0.4)$ & $0.7(-35)$ & 1.94 \\
\hline $\begin{array}{l}\text { Traditional Grocery } \\
\text { Jahnbajar }(\mathrm{n}=10)\end{array}$ & 1.5 & 0.8 & 2.8 & 7158.00 & 1.3 & 0.8 & 1.5 & 5165.00 & 0.8 & 0 & $\begin{array}{l}0.8 \\
(53.33)\end{array}$ & 1.96 \\
\hline $\begin{array}{l}\text { Traditional } \\
\text { Vegetable Entally } \\
(\mathrm{n}=10)\end{array}$ & 1.1 & 0.8 & 1.9 & 4027.00 & 0.8 & 0.9 & 1.7 & 1629.00 & 0.3 & $-(0.1)$ & $\begin{array}{l}0.2 \\
(-11.76)\end{array}$ & 2.03 \\
\hline $\begin{array}{l}\text { Traditional } \\
\text { Vegetable } \\
\text { Baithakhana }(n=10)\end{array}$ & 0.9 & 0.8 & 2.1 & 4129.00 & 0.7 & 1.2 & 1.5 & 1581.00 & 0.2 & $-(0.4)$ & $\begin{array}{l}-(0.2) \\
(-13.33)\end{array}$ & 2.06 \\
\hline $\begin{array}{l}\text { Traditional } \\
\text { Vegetable Jahnbajar } \\
(\mathrm{n}=10)\end{array}$ & 1.1 & 0.7 & 1.8 & 4008.00 & 0.6 & 0.7 & 1.3 & 1665.00 & 0.5 & 0 & $\begin{array}{l}0.5 \\
(38.46)\end{array}$ & 2.02 \\
\hline $\begin{array}{l}\text { Traditional Fruit } \\
\text { Entally }(n=10)\end{array}$ & 1.3 & 1.1 & 2.4 & 4223.00 & 0.8 & 1.2 & 1.7 & 2350.00 & 0.5 & $-(0.1)$ & $\begin{array}{l}0.4 \\
(-23.52)\end{array}$ & 1.93 \\
\hline $\begin{array}{l}\text { Traditional Fruit } \\
\text { Baithakhana }(n=10)\end{array}$ & 1.1 & 1.1 & 2.3 & 4165.00 & 0.7 & 1.4 & 1.8 & 2570.00 & 0.4 & $-(0.3)$ & $\begin{array}{l}0.1 \\
(-5.55)\end{array}$ & 1.86 \\
\hline $\begin{array}{l}\text { Traditional Fruit } \\
\text { Jahnbajar }(\mathrm{n}=10)\end{array}$ & 1.2 & 1.2 & 2.5 & 4011.00 & 0.9 & 1.3 & 1.9 & 2480.00 & 0.3 & $-(0.1)$ & $\begin{array}{l}0.2 \\
(-10.52)\end{array}$ & 1.85 \\
\hline
\end{tabular}

Table 6 shows the change in average man-days (number of laborers utilized per traditional retail outlet 2012-13 to 2016-17) in cluster Sealdah. From the table, it is noted that the number of average hired man-days has increased in all cases, but average family man-days have decreased in most of the cases except in all the traditional vegetable outlets which again proves the increase of employment in the selected area. It has been observed that the average man-days of laborers per traditional outlet have increased if family and hired laborers are considered as a whole.

Table 7 presents the change in average labor (number of laborers utilized per traditional retail outlet 201314 to 2016-17) in cluster Gariahat. From the table, it is noted that the number of average hired labor has increased in all cases, but the number of a family laborer is decreased or has remained the same in almost all of the traditional outlets. It is also seen that the average number of laborers per traditional 
Table 6: Change in Mandays (daily average per outlet) of Cluster Sealdah

\begin{tabular}{|c|c|c|c|c|c|c|c|c|c|c|}
\hline \multirow[b]{2}{*}{ Type of Traders } & \multicolumn{3}{|c|}{ 2016-17 } & \multicolumn{3}{|c|}{ 2010-11 } & \multicolumn{4}{|c|}{ Change from 2010-11 to 2016-17 } \\
\hline & $\begin{array}{l}\text { Hired } \\
\text { Mandays }\end{array}$ & $\begin{array}{l}\text { Family } \\
\text { Mandays }\end{array}$ & Total & $\begin{array}{l}\text { Hired } \\
\text { Mandays }\end{array}$ & $\begin{array}{l}\text { Family } \\
\text { Mandays }\end{array}$ & Total & $\begin{array}{l}\text { Hired } \\
\text { Mandays }\end{array}$ & $\begin{array}{l}\text { Family } \\
\text { Mandays }\end{array}$ & Total & $\begin{array}{l}\text { Percentage } \\
\text { change in } \\
\text { Mandays }\end{array}$ \\
\hline $\begin{array}{l}\text { Traditional } \\
\text { Grocery Entally }(n=10)\end{array}$ & 1.72 & 2.54 & 4.26 & 0.51 & 2.98 & 3.49 & 1.21 & $-(0.44)$ & 0.77 & 20.66 \\
\hline $\begin{array}{l}\text { Traditional Grocery } \\
\text { Baithakhana }(n=10)\end{array}$ & 1.77 & 2.52 & 4.29 & 0.74 & 2.68 & 3.42 & 1.02 & $-(0.15)$ & 0.87 & 25.40 \\
\hline $\begin{array}{l}\text { Traditional Vegetable } \\
\text { Entally }(\mathrm{n}=10)\end{array}$ & 0.55 & 1.32 & 1.88 & 0.46 & 1.49 & 1.96 & 0.08 & 0.12 & 0.21 & 11.04 \\
\hline $\begin{array}{l}\text { Traditional Vegetable } \\
\text { Baithakhana }(n=10)\end{array}$ & 0.51 & 1.46 & 1.98 & 0.33 & 1.13 & 1.47 & 0.18 & 0.07 & 0.25 & 17.05 \\
\hline $\begin{array}{l}\text { Traditional Fruit } \\
\text { Baithakhana }(n=10)\end{array}$ & 0.65 & 1.60 & 2.25 & 0.59 & 1.62 & 2.21 & 0.06 & $-(0.02)$ & 0.03 & 1.71 \\
\hline $\begin{array}{l}\text { Traditional Fruit Jahnbajar } \\
(\mathrm{n}=10)\end{array}$ & 0.71 & 1.56 & 2.27 & 0.41 & 1.66 & 2.08 & 0.29 & $-(0.10)$ & 0.19 & 9.31 \\
\hline
\end{tabular}

Table 7: Change in Average Labour Utilized Per Traditional Retail Outlet from 2012-13 to 2016-17 (ClusterGariahat) (No of Employees per Outlet)

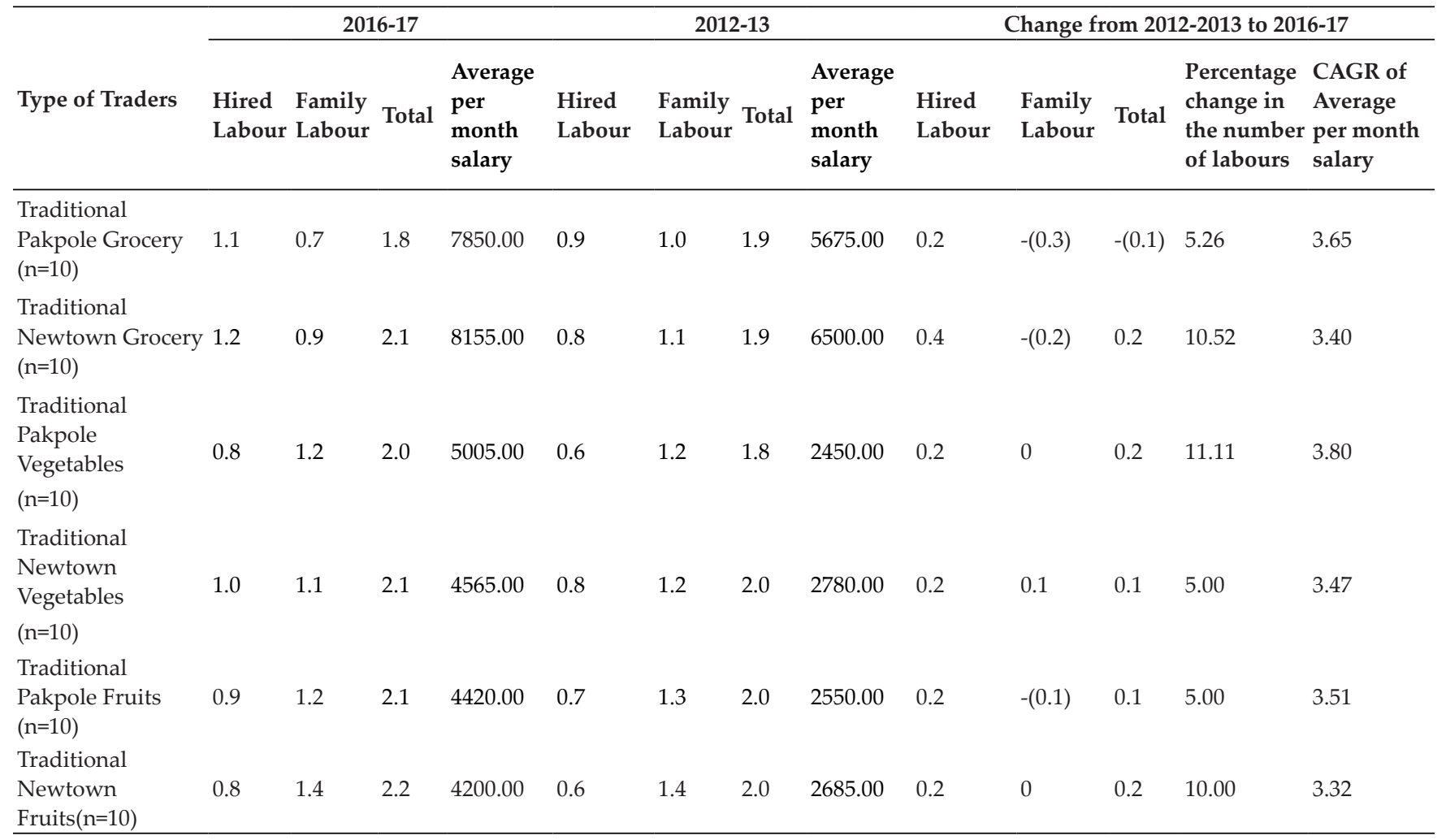

$n=$ Sub Sample Size.

outlet has increased if family and hired laborers are considered as a whole. It is further noted that the compound annual growth rates (CAGR) of average per month salary of laborers have increased in all traditional markets in the cluster Gariahat from 2013-14 to 2016-17 (i.e., before and after the 
establishment of the organized outlet in the area) which shows a positive change and hence there is no evidence of a decline in overall employment in the unorganized sector as a result of the entry of organized retailers.

Table 8 presents the change in average man-days (number of laborers utilized per traditional retail outlet 2013-14 to 2016-17) in cluster Gariahat. From the table, it is noted that the number of average higher man-days is increased in all cases, but average man-days are decreased in most of the cases except in traditional Gariahat grocery outlets. It is seen that average man-days of laborer per traditional outlet are increased if family and hired laborers are considered as a whole.

Table 9 presents the change in average labor (number of laborers utilized per traditional retail outlet (201314 to 2016-17) in cluster South Dumdum. From the

Table 8: Changes in Mandays from 2012-13 to 2016-17 (daily average per outlet)

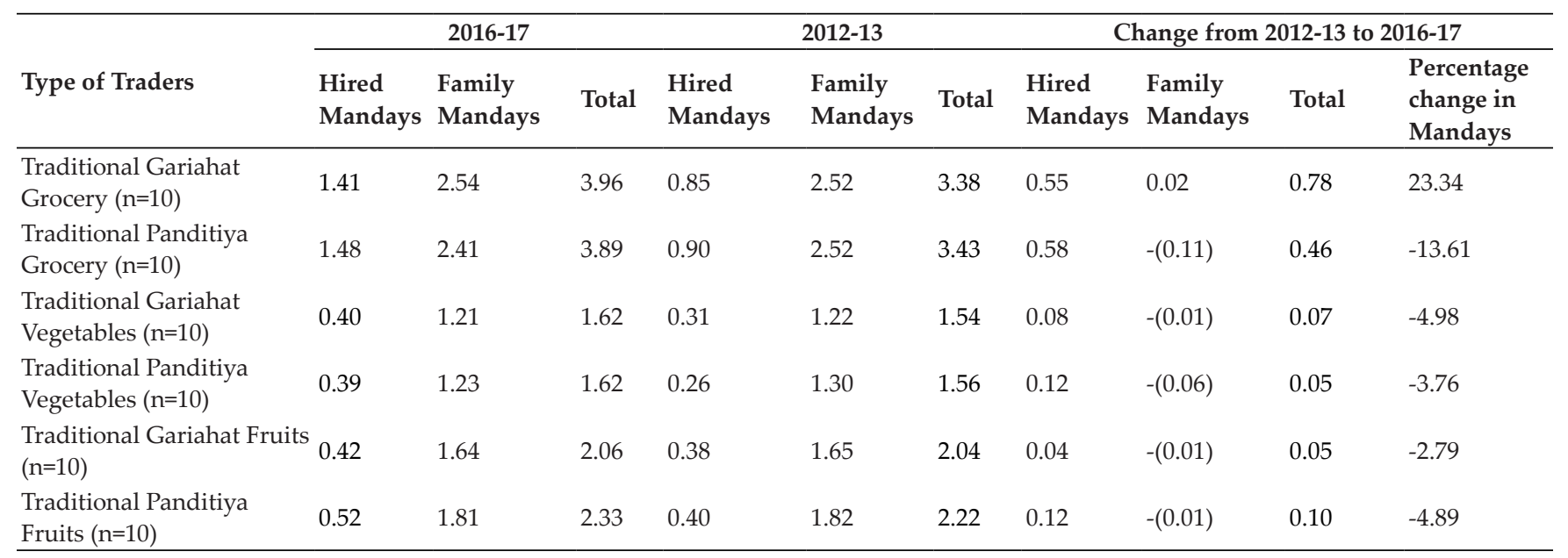

$n=$ Sub Sample Size.

Table 9: Change in Average Labour Utilized Per Traditional Retail Outlet from 2013-14 to 2016-17 (Cluster-South Dumdum) (No of Employees per Outlet)

\begin{tabular}{|c|c|c|c|c|c|c|c|c|c|c|c|c|}
\hline \multirow[b]{2}{*}{ Type of Traders } & \multicolumn{4}{|c|}{ 2016-17 } & \multicolumn{4}{|c|}{ 2013-14 } & \multicolumn{4}{|c|}{ Change from 2013-14 to 2016-17 } \\
\hline & $\begin{array}{l}\text { Hired } \\
\text { Labour }\end{array}$ & $\begin{array}{l}\text { Family } \\
\text { Labour }\end{array}$ & Total & $\begin{array}{l}\text { Average } \\
\text { per month } \\
\text { salary }\end{array}$ & $\begin{array}{l}\text { Hired } \\
\text { Labour }\end{array}$ & $\begin{array}{l}\text { Family } \\
\text { Labour }\end{array}$ & Total & $\begin{array}{l}\text { Average } \\
\text { per } \\
\text { month } \\
\text { salary } \\
\end{array}$ & $\begin{array}{l}\text { Hired } \\
\text { Labour }\end{array}$ & $\begin{array}{l}\text { Family } \\
\text { Labour }\end{array}$ & Total & $\begin{array}{l}\text { CAGR of } \\
\text { Average per } \\
\text { month salary }\end{array}$ \\
\hline $\begin{array}{l}\text { Traditional Nagerbajar } \\
\text { Grocery }(n=10)\end{array}$ & 1.2 & 1.1 & 2.3 & 6875.00 & 1.1 & 1.3 & 2.4 & 5575.00 & 0.1 & -0.2 & $\begin{array}{l}-0.1 \\
(-4.16)\end{array}$ & 5.00 \\
\hline $\begin{array}{l}\text { Traditional Subhashnagar } \\
\text { Grocery }(n=10)\end{array}$ & 1.1 & 1.2 & 2.3 & 5870.00 & 1.0 & 1.5 & 2.5 & 4725.00 & 0.1 & -0.3 & $\begin{array}{l}-0.2 \\
(-8.00)\end{array}$ & 4.81 \\
\hline $\begin{array}{l}\text { Traditional Kalindi } \\
\text { Grocery }(\mathrm{n}=10)\end{array}$ & 1.2 & 1.2 & 2.4 & 6500.00 & 0.9 & 1.1 & 2 & 5650.00 & 0.3 & 0.1 & $\begin{array}{l}0.4 \\
(20.00)\end{array}$ & 4.39 \\
\hline $\begin{array}{l}\text { Traditional Nagerbajar } \\
\text { Vegetables }(n=10)\end{array}$ & 0.8 & 1.1 & 1.9 & 4575.00 & 0.5 & 1.2 & 1.7 & 3460.00 & 0.3 & -0.1 & $\begin{array}{l}0.2 \\
(11.76)\end{array}$ & 4.77 \\
\hline $\begin{array}{l}\text { Traditional Subhashnagar } \\
\text { Vegetables }(n=10)\end{array}$ & 0.5 & 1.3 & 1.8 & 4280.00 & 0.4 & 1.5 & 1.9 & 3275.00 & 0.1 & -0.2 & $\begin{array}{l}-0.1 \\
(-5.26)\end{array}$ & 4.63 \\
\hline $\begin{array}{l}\text { Traditional Kalindi } \\
\text { Vegetables }(n=10)\end{array}$ & 0.7 & 1.1 & 1.8 & 4470.00 & 0.5 & 1.2 & 1.7 & 3370.00 & 0.2 & -0.1 & $\begin{array}{l}0.1 \\
(5.88)\end{array}$ & 4.74 \\
\hline $\begin{array}{l}\text { Traditional Nagerbajar } \\
\text { Fruits }(n=10)\end{array}$ & 0.9 & 1.2 & 2.1 & 4760.00 & 0.6 & 1.1 & 1.7 & 4055.00 & 0.3 & 0.1 & $\begin{array}{l}0.2 \\
(11.76)\end{array}$ & 4.15 \\
\hline $\begin{array}{l}\text { Traditional Subhashnagar } \\
\text { Fruits }(n=10)\end{array}$ & 0.7 & 1.4 & 2.1 & 4250.00 & 0.5 & 1.2 & 1.7 & 3570.00 & 0.2 & 0.2 & $\begin{array}{l}0.4 \\
(23.52)\end{array}$ & 4.10 \\
\hline $\begin{array}{l}\text { Traditional Kalindi Fruits } \\
(\mathrm{n}=10)\end{array}$ & 0.8 & 1.1 & 1.9 & 4350.00 & 0.6 & 1.2 & 1.8 & 3575.00 & 0.2 & -0.1 & $\begin{array}{l}0.1 \\
(5.55)\end{array}$ & 4.27 \\
\hline
\end{tabular}

$n=$ Sub sample size. 
table, it is noted that the number of average higher labor has increased in all cases, but the number of family laborer has either decreased or remained the same in almost of the cases. It is seen that the average number of laborers per traditional outlet has increased if family and hired laborers are considered as a whole. It is further noted that the compound annual growth rates (CAGR) of average per month salary of laborers have increased in all traditional markets in the cluster South Dumdum from 2013-14 to 2016-17 (i.e., before and after the establishment of the organized outlet in the area) which shows a positive change and hence there is no evidence of a decline in overall employment in the unorganized sector as a result of the entry of organized retailers.

Table 10 shows the change in average man-days (number of laborers utilized per traditional retail outlet 2012-13 to 2016-17) in cluster South Dumdum. From the table, it is noted that the number of average hired man-days have increased in all cases, but average family man-days have decreased in most of the cases except in all the traditional vegetable outlets which mostly shows the increase of employment in the selected area. It has been observed that the average man-days of laborers per traditional outlet is increased if family and hired laborers are considered as a whole.
Table 11 presents the change in average labor (number of laborers utilized per traditional retail outlet 2012-13 to 2016-17) in cluster Gopalpur. From the table, it is noted that the number of average hired labor is increased in all cases, but the number of family laborers is decreased in most of the cases except in traditional Teghoria and Baguihati vegetable outlets. It is seen that the compound annual growth rates (CAGR) of average per month salary of laborers have increased in all traditional markets in the cluster Gopalpur from 2012-13 to 2016-17 (i.e., before and after the establishment of the organized outlet in the area) which shows a positive change and hence there is no evidence of a decline in overall employment in the unorganized sector as a result of the entry of organized retailers.

Table 12 presents the change in average man-days (number of laborers utilized per traditional retail outlet 2012-13 to 2016-17) in cluster Gopalpur. From the table, it is noted that the number of average hired man-days has increased in all cases, but average family man-days have decreased in most of the cases except in Teghoria Vegetables and Baguihati fruit outlets. It is seen that average mandays of laborer per traditional outlet are increased if family and hired laborers are considered as a whole. Table 13 presents the change in average labor

Table 10: Change in Mandays (daily average per outlet) of Cluster South Dumdum

\begin{tabular}{|c|c|c|c|c|c|c|c|c|c|c|}
\hline \multirow[b]{2}{*}{ Type of Traders } & \multicolumn{3}{|c|}{ 2016-17 } & \multicolumn{3}{|c|}{ 2013-14 } & \multicolumn{4}{|c|}{ Change from 2013-14 to 2016-17 } \\
\hline & $\begin{array}{l}\text { Hired } \\
\text { Mandays }\end{array}$ & $\begin{array}{l}\text { Family } \\
\text { Mandays }\end{array}$ & Total & $\begin{array}{l}\text { Hired } \\
\text { Mandays }\end{array}$ & $\begin{array}{l}\text { Family } \\
\text { Mandays }\end{array}$ & Total & $\begin{array}{l}\text { Hired } \\
\text { Mandays }\end{array}$ & $\begin{array}{l}\text { Family } \\
\text { Mandays }\end{array}$ & Total & $\begin{array}{l}\text { Percentage } \\
\text { change in } \\
\text { Mandays }\end{array}$ \\
\hline $\begin{array}{l}\text { Traditional Nagerbajar } \\
\text { Grocery }(\mathrm{n}=10)\end{array}$ & 1.47 & 2.43 & 3.80 & 0.98 & 2.63 & 3.62 & 0.48 & -0.19 & 0.28 & 7.86 \\
\hline $\begin{array}{l}\text { Traditional Subhashnagar } \\
\text { Grocery }(\mathrm{n}=10)\end{array}$ & 1.52 & 2.38 & 3.91 & 0.80 & 2.56 & 3.37 & 0.71 & -0.18 & 0.53 & 15.98 \\
\hline $\begin{array}{l}\text { Traditional Kalindi Grocery } \\
(\mathrm{n}=10)\end{array}$ & 1.40 & 2.40 & 3.81 & 0.91 & 2.50 & 3.41 & 0.49 & -0.09 & 0.39 & 11.56 \\
\hline $\begin{array}{l}\text { Traditional Nagerbajar } \\
\text { Vegetables }(n=10)\end{array}$ & 0.35 & 1.31 & 1.67 & 0.23 & 1.11 & 1.35 & 0.11 & 0.19 & 0.31 & 23.42 \\
\hline $\begin{array}{l}\text { Traditional Subhashnagar } \\
\text { Vegetables }(\mathrm{n}=10)\end{array}$ & 0.47 & 1.27 & 1.74 & 0.37 & 1.42 & 1.79 & 0.09 & -0.15 & -0.05 & -3.00 \\
\hline $\begin{array}{l}\text { Traditional Kalindi } \\
\text { Vegetables }(n=10)\end{array}$ & 0.44 & 1.37 & 1.82 & 0.34 & 1.22 & 1.56 & 0.10 & 0.15 & 0.25 & 16.21 \\
\hline $\begin{array}{l}\text { Traditional Nagerbajar Fruits } \\
(\mathrm{n}=10)\end{array}$ & 0.58 & 1.41 & 1.99 & 0.46 & 1.30 & 1.77 & 0.11 & 0.10 & 0.21 & 12.35 \\
\hline $\begin{array}{l}\text { Traditional Subhashnagar } \\
\text { Fruits }(\mathrm{n}=10)\end{array}$ & 0.76 & 1.46 & 2.22 & 0.59 & 1.39 & 1.99 & 0.17 & 0.06 & 0.23 & 11.90 \\
\hline $\begin{array}{l}\text { Traditional Kalindi Fruits } \\
(\mathrm{n}=10)\end{array}$ & 0.61 & 1.55 & 2.17 & 0.50 & 1.44 & 1.95 & 0.10 & 0.10 & 0.21 & 10.93 \\
\hline
\end{tabular}

$n=$ Sub sample size. 
Table 11: Change in Average Labour Utilized Per Traditional Retail Outlet from 2012-13 to 2016-17 (ClusterGopalpur) (No of Employees per Outlet)

\begin{tabular}{|c|c|c|c|c|c|c|c|c|c|c|c|c|}
\hline \multirow[b]{2}{*}{ Type of Traders } & \multicolumn{4}{|c|}{ 2016-17 } & \multicolumn{4}{|c|}{ 2012-13 } & \multicolumn{4}{|c|}{ Change from 2012-2013 to 2016-17 } \\
\hline & $\begin{array}{l}\text { Hired } \\
\text { Labour }\end{array}$ & $\begin{array}{l}\text { Family } \\
\text { Labour }\end{array}$ & Total & $\begin{array}{l}\text { Average } \\
\text { per month } \\
\text { salary }\end{array}$ & $\begin{array}{l}\text { Hired } \\
\text { Labour }\end{array}$ & $\begin{array}{l}\text { Family } \\
\text { Labour }\end{array}$ & Total & $\begin{array}{l}\text { Average } \\
\text { per month } \\
\text { salary }\end{array}$ & $\begin{array}{l}\text { Hired } \\
\text { Labour }\end{array}$ & $\begin{array}{l}\text { Family } \\
\text { Labour }\end{array}$ & Total & $\begin{array}{l}\text { CAGR of } \\
\text { Average } \\
\text { per month } \\
\text { salary }\end{array}$ \\
\hline $\begin{array}{l}\text { Traditional Teghoria } \\
\text { Grocery }(\mathrm{n}=10)\end{array}$ & 1.3 & 0.7 & 2.0 & 7450.00 & 1.1 & 1.0 & 2.1 & 5055.00 & 0.2 & $(-) 0.3$ & $\begin{array}{l}(-) 0.1 \\
-(4.76)\end{array}$ & 3.74 \\
\hline $\begin{array}{l}\text { Traditional Baguihati } \\
\text { Grocery }(n=10)\end{array}$ & 1.2 & 0.9 & 2.1 & 8065.00 & 1.0 & 1.1 & 2.1 & 6850.00 & 0.2 & $(-) 0.2$ & $\begin{array}{l}0 \\
(0.00)\end{array}$ & 3.13 \\
\hline $\begin{array}{l}\text { Traditional Teghoria } \\
\text { Vegetables }(\mathrm{n}=10)\end{array}$ & 0.9 & 1.1 & 2.0 & 5175.00 & 0.8 & 1.0 & 1.8 & 2750.00 & 0.1 & 0.1 & $\begin{array}{l}0 \\
(0.00)\end{array}$ & 3.75 \\
\hline $\begin{array}{l}\text { Traditional Baguihati } \\
\text { Vegetables }(\mathrm{n}=10)\end{array}$ & 1.1 & 1.1 & 2.2 & 4455.00 & 0.9 & 1.1 & 1.9 & 3175.00 & 0.2 & 0 & $\begin{array}{l}0.2 \\
(10.52)\end{array}$ & 3.18 \\
\hline $\begin{array}{l}\text { Traditional Teghoria } \\
\text { Fruits }(\mathrm{n}=10)\end{array}$ & 0.9 & 1.2 & 2.1 & 4500.00 & 0.7 & 1.3 & 2.0 & 2995.00 & 0.2 & $(-) 0.1$ & $\begin{array}{l}0.1 \\
(5.00)\end{array}$ & 3.32 \\
\hline
\end{tabular}

$n=$ Sub Sample Size.

Table 12: Change in Mandays (daily average per outlet) of the Cluster Gopalpur

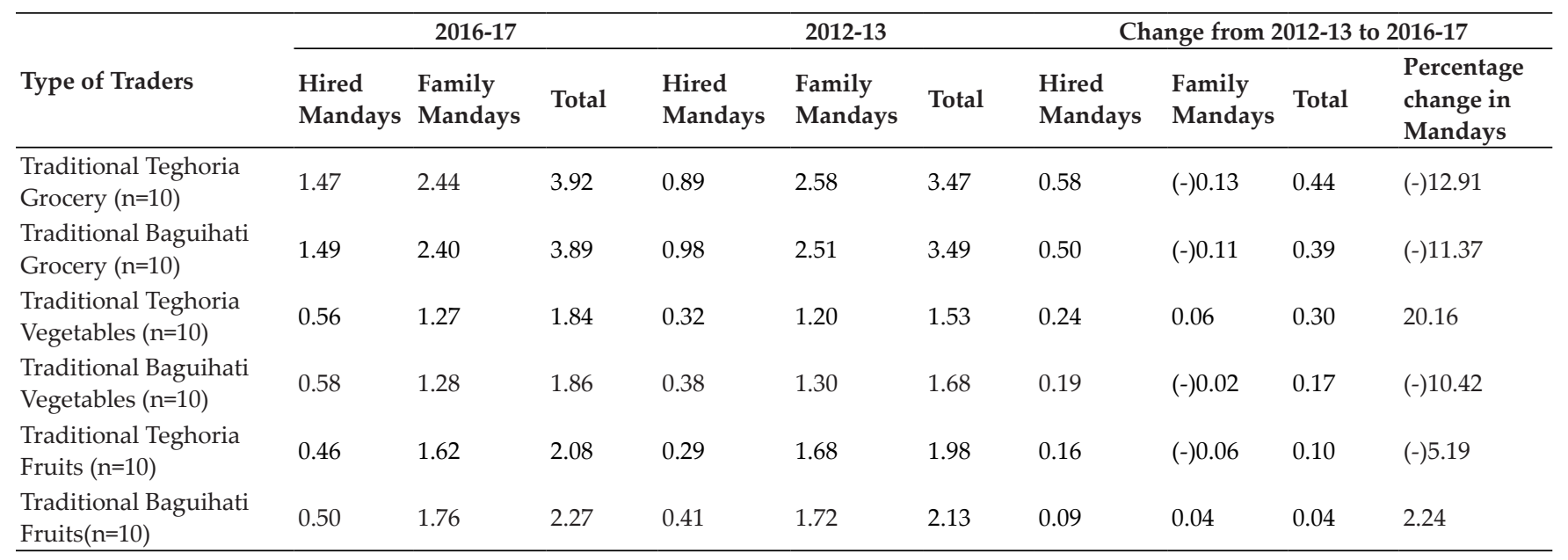

$n=$ Sub Sample Size.

(number of laborers utilized per traditional retail outlet 2012-13 to 2016-17) in cluster Newtown. From the table, it is noted that the number of average hired labor is increased in all cases, but the number of family laborers is decreased in most of the cases except in traditional Newtown grocery outlets. It is seen that an average number of laborers per traditional outlet is increased if family and hired laborers are considered as a whole. It is further noted that the compound annual growth rates (CAGR) of average per month salary of laborers have increased in all traditional markets in the cluster Newtown from 2012-13 to 2016-17 (i.e., before and after the establishment of the organized outlet in the area) which shows a positive change and hence there is no evidence of a decline in overall employment in the unorganized sector as a result of the entry of organized retailers.

Table 14 presents the change in average man-days (number of laborers utilized per traditional retail outlet 2012-13 to 2016-17) in cluster Newtown. From the table, it is noted that the number of average higher man-days is increased in all cases, but average man-days are decreased in most of the cases except in traditional Newtown grocery outlets. It is seen that the average man-days of laborer per traditional outlet are increased if family and hired laborers are considered as a whole. 
Table 13: Change in Average Labour Utilized per Traditional Retail Outlet from 2013-14 to 2016-17 (ClusterNewtown) (No of Employees per Outlet)

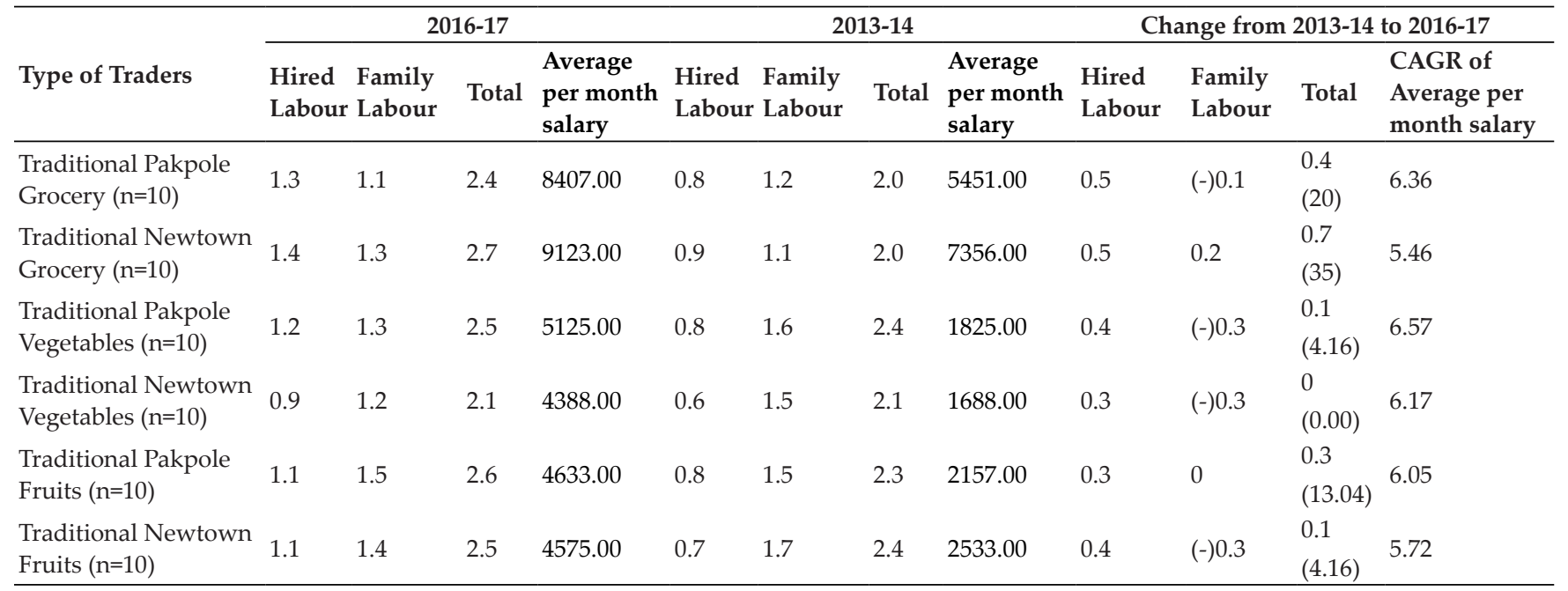

$n=$ Sub Sample Size.

Table 14: Change in Mandays (daily average per outlet) (Cluster-Newtown)

\begin{tabular}{|c|c|c|c|c|c|c|c|c|c|}
\hline \multirow[b]{2}{*}{ Type of Traders } & \multicolumn{3}{|c|}{ 2016-17 } & \multicolumn{3}{|c|}{ 2012-13 } & \multicolumn{3}{|c|}{ Change from $2012-13$ to $2016-17$} \\
\hline & $\begin{array}{l}\text { Hired } \\
\text { Mandays }\end{array}$ & $\begin{array}{l}\text { Family } \\
\text { Mandays }\end{array}$ & Total & $\begin{array}{l}\text { Hired } \\
\text { Mandays }\end{array}$ & $\begin{array}{l}\text { Family } \\
\text { Mandays }\end{array}$ & Total & $\begin{array}{l}\text { Hired } \\
\text { Mandays }\end{array}$ & $\begin{array}{l}\text { Family } \\
\text { Mandays }\end{array}$ & Total \\
\hline Traditional Pakpole Grocery $(\mathrm{n}=10)$ & 1.62 & 2.86 & 4.48 & 0.75 & 2.52 & 3.27 & 0.87 & 0.337 & $1.21(37.00)$ \\
\hline Traditional Pakpole Vegetables (n=10) & 0.44 & 1.17 & 1.61 & 0.33 & 1.32 & 1.66 & 0.10 & $(-) 0.15$ & $(-) 0.04(-2.76)$ \\
\hline Traditional Newtown Vegetables $(n=10)$ & 0.36 & 1.23 & 1.59 & 0.33 & 1.46 & 1.77 & 0.02 & $(-) 0.22$ & $(-) 0.18(-10.16)$ \\
\hline Traditional Pakpole Fruits $(n=10)$ & 0.55 & 1.66 & 2.21 & 0.41 & 1.55 & 1.96 & 0.13 & 0.11 & $0.25(12.75)$ \\
\hline
\end{tabular}

Figures in the parentheses indicate the percentages to the total $n=$ Sub Sample Size.

Table 15: Income and Employment in the Organized Outlets of all the Clusters in Kolkata

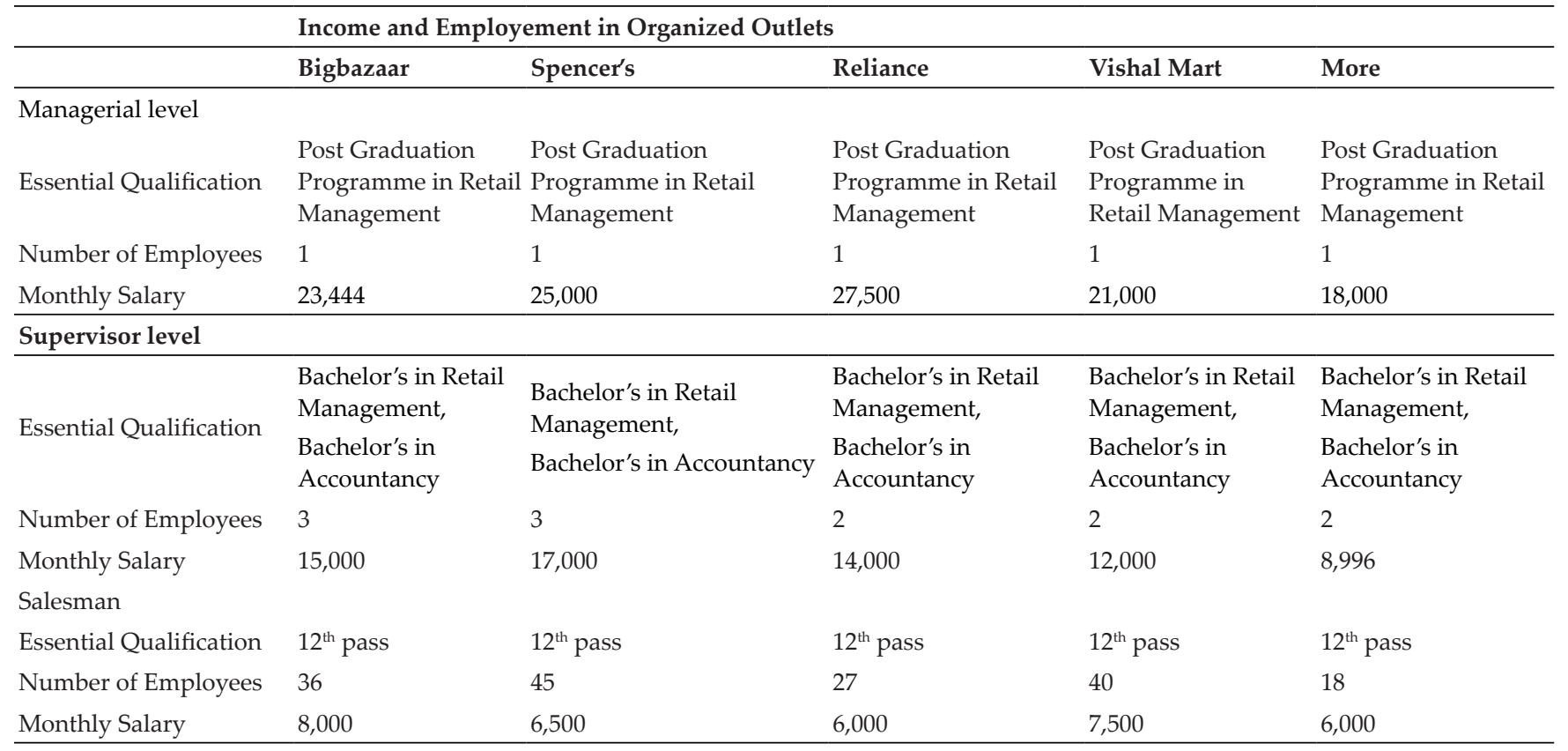


Table 15 shows the income and employment opportunities in organized outlets in Kolkata city. From the table, it is clearly understood that the essential qualification for the managerial post, supervisor post, and salesman post are post-graduation, graduation, and class $12^{\text {th }}$ pass, respectively. It is also found that in all cases, there is only one employee at the managerial level, and there are two to three employees at the supervisor level in each case. But at the level of salesman number of employees' ranges from 18 to 45 . From the table, it is further noted that per month salary at the managerial level is observed to be the highest at reliance and lowest in case of more.

\section{RESULTS}

The study has concluded that in the case of unorganized retailing, the retailers in the vicinity of organized retailers in Kolkata City have experienced a slight decline in their volume of business and profit in the initial years after the entry of large organized retailers, there was an impact on sales and profit weakened over time, but there was no evidence of a decline in overall employment in the unorganized sector as a result of the entry of organized retailers. The number of average hired laborers has increased in all cases, but the number of family laborers has either decreased or remained the same in almost all the cases. The CAGR of per month average salary of the laborers have also increased in all the cases when before and after the establishment of the organized outlet in the concerned study area is taken into consideration. Whereas, in the case of organized outlets, apart from providing direct employment in retail, it is also providing the growth of a number of activities in the economy, which in turn is opening up employment opportunities to several people. This includes the small manufacturing sector especially foodprocessing, construction, packing, IT, transport, cold chain, and other infrastructure. It may be affecting some amount of employment in unorganized retail and the trade intermediaries associated with the traditional supply channels, but the additional jobs are also created, which is much higher than those that are lost.
An important point is also observed, that, while the employment opportunities in organized outlets in Kolkata city shows displaces some of the low-end, low-quality, underproductive ones, but the new jobs created are the high quality, productive ones. It also creates a number of job opportunities for unskilled labor for the tasks of sorting, grading, labeling, etc., which shows a positive-sum game in which both unorganized and organized retail not only coexist but also grow substantially in size. The majority of unorganized retailers surveyed in this study indicated their preference to continue in the business and compete rather than exit. Hence, this growth of organized retail in Kolkata City is not only enhancing the employment potential of the state but the Indian economy as a whole.

\section{REFERENCES}

Somayajulu, G. and Venkataramana,V. 2002. Issues \& Challenges for Organized Retailing in India. Indian J. Mark., XXXII(8): 16-21.

Vij, S. 2013.The Study and the Analysis: An Impact of Organized Retail on Unorganized Retail in India. Excel. Int. J. Multi Mgt. Stud., 3(7).

Kanwaljeet, M. 2015. Organized Retailing in India: Opportunities and Challenges, IJCBM Int. J. Comm., 4(2).

Punit, K. Amit, K. and Virendra, M. 2015. An Economic Study of Consumer Behaviour toward Organised Food Retail in National Capital Region of India. Econ. Aff., 60(4).

Bhandani, S. 2016. Survey on Organized and Unorganized Sectors in Campus of JNU. Int. J. Dev. Res., 6(1): 6560-6565.

Chandrashekhar, L. 2016. A Study on Organized Retail on Unorganized Retail Outlets in Mysore City. Int. J. Business Study Mgt., 3(4).

Gandhi and Chinnadorai. 2017. Retail in India. Int. J. Engg. Dev. Res., 5(1). 
